\title{
Exploring Barriers Contributing towards an Effective Online Learning among Undergraduates' Students using PLS-SEM
}

\author{
Nurul Aien Abd Aziz', Mohd Hafizan Musa², Noreen Noor Abd Aziz', Shaherah Abdul Malik, \\ Rusnani Mohamad Khalid ${ }^{5}$, Nurliana Nasution ST MKom ${ }^{6}$
}

\author{
1,3,4 Faculty of Business Management, Universiti Teknologi MARA Johor, Malaysia \\ 2,5 Faculty Computer and Mathematical Sciences, Universiti Teknologi MARA Johor, Malaysia \\ 6 Faculty of Computer Sciences, Universiti Lancang Kuning-Pekanbaru-Riau, Indonesia
}

nurul106@uitm.edu.my, mohdh233@uitm.edu.my,noree974@uitm.edu.my, shahe314@uitm.edu.my, rusna162@uitm.edu.my,nurliananst@unilak.co.id

\begin{abstract}
In March 2020, the world was first hit by Covid-19 that started to have negative impact on all sectors including education. Most of the higher learning institutions had a shift to use the technology in imparting knowledge and conducting online learning for students. This paper analyzed the effect of attitude, interruption, personal skills and technology skills towards effective online learning. A total of 375 valid questionnaire responses was coded and analyzed using PLS-SEM analysis. The findings showed the attitude and technology skills were significant factors to the barriers of effective online learning among students.
\end{abstract}

Keywords: Online Learning; Technology; Education learning; Technology skill

eISSN: 2398-4287@ 2020. The Authors. Published for AMER ABRA cE-Bs by e-International Publishing House, Ltd., UK. This is an open access article under the CC BYNCND license (http://creativecommons.org/licenses/by-nc-nd/4.0/). Peer-review under responsibility of AMER (Association of Malaysian Environment-Behaviour Researchers), ABRA (Association of Behavioural Researchers on Asians) and cE-Bs (Centre for Environment-Behaviour Studies), Faculty of Architecture, Planning \& Surveying, Universiti Teknologi MARA, Malaysia.

DOI: https://doi.org/10.21834/ebpj.v5i15.2511.

\subsection{Introduction}

Nowadays, most of the higher learning institutions have begun to transform their face-to-face teaching and learning to online methods. They have taken a step to change educational lessons and learning deliveries through online mode. Presently, the existence of technology is to comfort people's daily practices. Technology is universally used including in the field of education. Every year, the statistics show an increase in the number of students using online learning. The existence of internet network system has created good market potentials for higher learning institutions to implement online learning (Donoghue \& Worton, 2002). Through online platforms, the implementation of online learning sessions covers various locations and time more comprehensively. Although there are many challenges faced during this online implementation phase, most higher learning institutions have successfully explored and developed online learning as their new platform for knowledge delivery.

The online learning system is defined as distance learning and network learning (Wilson, 2001). Online learning methods facilitate interaction between lecturers and students (Holley, 2002). The Covid-19 pandemic has caused educators to work from home, and this is a change that must be faced by them to continue educating their students. Distance education aims to expand the value of education, the appropriateness of education, to increase access and equitable development of education.

Various creative methods are used to impart knowledge to students through online methods like videos, digital slideshows, infographics, and others. The application of technology has made educators becoming more creative in developing ideas and thoughts to convey knowledge. Along with the development of technology, universities need to withstand the current of change not to be left behind (Volery, 2000). To strengthen online learning implementation methods, the roles of academia and the students are crucial. They need to

eISSN: 2398-4287@ 2020. The Authors. Published for AMER ABRA cE-Bs by e-International Publishing House, Ltd., UK. This is an open access article under the CC BYNCND license (http://creativecommons.org/licenses/by-nc-nd/4.0/). Peer-review under responsibility of AMER (Association of Malaysian Environment-Behaviour Researchers), ABRA (Association of Behavioural Researchers on Asians) and cE-Bs (Centre for Environment-Behaviour Studies), Faculty of Architecture, Planning \& Surveying, Universiti Teknologi MARA, Malaysia.

DOI: https://doi.org/10.21834/ebpj.v5i15.2511. 
provide a reliable support to develop this platform further and strive to create a conducive environment for online learning (O'Hearn, 2000). The success of online education is challenging to be achieved and implemented without constant interaction and support from both staff and students. Volery (2000) stated that the interaction between lecturers and students dominates the learning environment.

The presence of Covid-19 pandemic in March 2020 had opened a new chapter in the history of Malaysian education. Most universities had switched to online learning methods (Lloyd, Byrne, \& Mccoy, 2012). Furthermore, online course offerings also increase, showing a high and positive demand for this platform. This is a good signal for higher learning institutions to explore the potentials of online learning methods. Behind the implementation of online learning, there are many obstacles to implementing it. According to LeBlanc, Pruchnicki, Rohdieck, Khurma, \& Dasta (2000), to develop online learning sessions, support from top management is very important, which include training, rules, and evaluations. To ensure the effectiveness of online learning, higher learning institutions should explore and come up with initiatives to examine the critical success factors of online learning (Fauziah, 2014). Online learning methods can positively impact the students in continuing their learning sessions. Therefore, this study examines the factors contributing to the barriers of effective online learning among UiTM Johor's undergraduates. Three hundred and seventy-five respondents comprising of undergraduates from UiTM Johor participated in this survey. Simple random sampling Method was used to measure attitudes, interruptions, personal skills and technological skills with the barriers contributing to effective online learning.

\subsection{Literature Review}

A positive attitude is one of the significant successes of studying online (Harasim et al.,1997). The attitude towards online learning is an example of people's feelings towards the use of online learning. It is regarded as an assessment description of whether the user likes or dislikes the use of online learning (Sum, Hericko, Pusnik, \& Polancic, 2011). With this platform's usage growing over time, it has now become a common practice among undergraduates. Online learning allows learners to be more self-directed than traditional education in several ways. A student needs some amount of independence and maturity when being self-directed. Many research studies indicate that the use of online learning has a significant impact across several stages of education, beginning from childhood to becoming a university student (Peytcheva-Forsyth, Yovkova, \& Aleksieva, 2018). Since students show a positive attitude towards online learning, joining this platform is a good sign for higher learning institutions (Aziz, Musa, Ghul, Aziz, \& Khalid, 2018).

One of the determinants used to measure the success of online learning is technological skills. Here, computer knowledge, online knowledge, and literacy in computer applications are involved (Fauziah, 2014). Some lecturers disagree with online teaching because they do not think that it necessarily solves difficult problems with teaching and learning (Conlon, 1997), however others are worried about the many challenges that impede successful online teaching and learning. Lecturers and students need to develop the skills to help them use this technology to excel in online learning (Oliver, 2001). To sustain online learning operations, universities need to have full infrastructure facilities (Pirani, 2004). To be more successful, lecturers and students must have technical skills and expertise to handle learning instruments. These concerns include the evolving nature of technology, the difficulty of network systems, the lack of online learning environment security, and the limited awareness of how much lecturers and students need to know about effective engagement using communication and information technology (Brandt, 1996). The absence of expertise hampers the achievement of the learning goals of online learning sessions, as they need to be accompanied by technical knowledge that aids execution.

Interruption refers to stopping something from happening in a short period. For the online learning methods, one of the essential requirements is the students are required to have good internet access. One of the reasons that contribute to internet interruption is the lack of facilities. This interruption is also classified to native learners, students with learning disabilities, and ageing learners (Oliver \& Towers, 2000). For them, moving to online learning often carries more barriers than opportunities. Access to online courses is also crucial and needs to be implemented with complete infrastructure (Oliver, 2001). The students are not the only ones who are required to have a good internet connection to establish the online learning session. All other parties that are involved in the session must also have a good internet connection, including the teachers and lecturers too. If the problem appears to any of the parties, it can cause another notorious pain like internet delay (Lee, Choo, lannaccone \& Moon). Hence, interference in various forms should be avoided with the aim of being achieved a successful online learning session.

Online learning has shown significant growth over the past few years. Since the Covid-19 epidemic, online education has turned out to become one of the popular methods to deliver knowledge in schools and universities. The online learning method has altered the faceto-face learning into new ways. Even with these new compulsory changes in learning methods, there are still many students who do not have the skills and experiences to undertake online learning activities in their ways (Oliver, 2001). According to Oliver and Towers (2000). The effectiveness of online learning depends on adequate internet infrastructures and the skills of both students and instructors. To overcome the weaknesses, universities and schools can assist them by providing training and skill development courses (Oliver, 2001).

The existence of technology has facilitated the life and work of all individuals. It is widely used in various fields includes education. Each year, there is an increase in at least one online course (Allen \& Seaman, 2013). To enhance an online learning platform, there must be a barrier. A barrier is defined as something that prevents a process from running smoothly and completely. Studies conducted by Muilenburg and Berge (2005), and Abramenka (2015) also evaluated some of the barriers that contribute to online implementation. In the execution of online learning, the quality of systems and information are two interrelated dimensions in the use of information technology applications. Both rates determine the output produced from electronic learning systems as one of the services of technology in education. Therefore, the development and innovation in electronic learning systems are done by educational institutions. Nowadays, universities are also competing to increase the benefits of technology-based teaching and learning systems. 


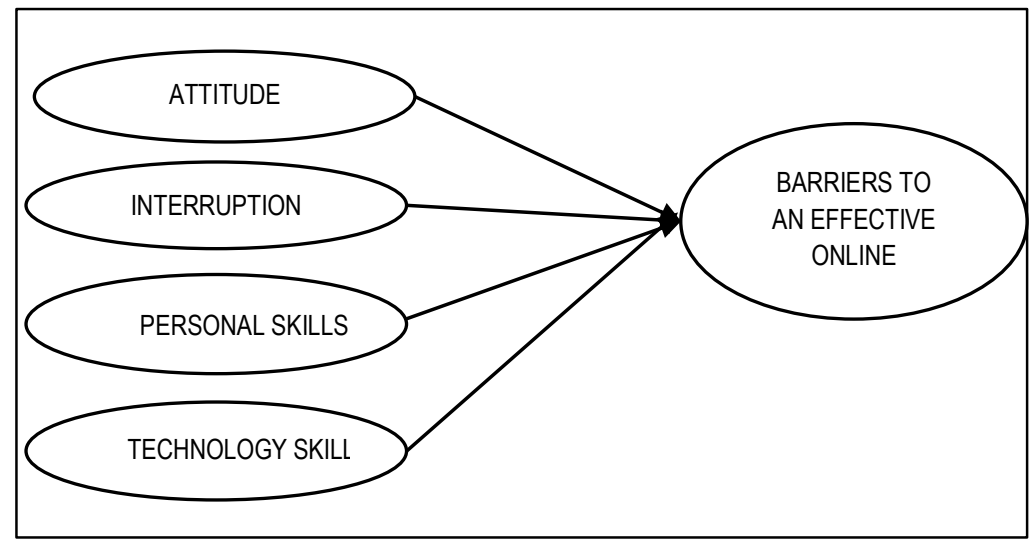

Figure 1: Theoretical framework

\subsection{Methodology}

The data was analysed using Partial Least Squares Model Analysis (PLS). Abdul Hafaz Ngah (2014) and Shahriar et al. (2011) indicated that PLS is useful to evaluate empirical validation and theoretical conceptualization. The data were examined using the measurement model and considered using confirmatory factor analysis. To measure the structural model measurement, the standard path coefficient and $\mathrm{t}$-statistics $(\mathrm{t}>1.96)$ were used.

\subsection{Findings}

\section{Demographic Result}

The sample profiles revealed that 77.3 per cent of the respondents in this study were females, and 22.7 per cent were males. 66.8 per cent of the respondents aged between 21 and 30, while 28.2 per cent of respondents aged between 18 and 20 years, representing the second-highest group. 72.3 per cent of them were doctoral students, while 27.7 per cent were diploma students. 73.8 per cent were fulltime students, and the remainder were part-time students (26.2 per cent). About 85.8 per cent of the respondents came from business backgrounds, followed by 9.7 per cent coming from information technology and computer science

\section{Measurement Model}

As indicated by Fornell and Larcker (1981), convergent validity is measured using item reliability, average variance extracted (AVE) and internal accuracy. The loading score for each item are calculated using item reliability. The extensive item loadings are presented in Table 1. The loadings display the correlation with their respective constructs of the objects. The findings indicate that all things that can be considered appropriate are more signicant than 0.7 (Chin, 2003).

Table 1 also illustrated that the scores for all AVE values were above 0.5. As denoted in Average Variance Extracted (AVE), the most signicant value was 0.740 for personal skills, while the lowest was 0.613 for attitudes. Therefore, Internal Consistency encountered the standard for a minimum value of 0.7 . Based on the reviewed results, they discovered the most insufcient internal consistency, which was 0.877 for interruptions, and the highest was personal skills $(0.934)$. The reliability of the measurement model was used to confirm the high internal consistency values for all constructs. Consequently, the measurement model achieved all three necessary criterion and convergent validity. Hence, the results clearly explained that the items in each construct were signicantly correlated and reliable.

The first criterion for discrimination is calculated using the extracted average variance power source (AVE). The value is associated with the inter-construct correlation. The square roots of the AVE were calculated and used to achieve the validity criteria as presented in the main diagonal of Table 2. The off-diagonal elements indicate the relationship between the latent variables. Discriminant validity is reached when the value of the square root of the AVE of a construct is more signicant than its correlation comparing with another construct (Barclay, Higgins, and Thompson 1995). The results in table 2 approved that the discriminant validity was achieved.

Referring to the score of cross loading matrix, all the items loaded higher on the construct as it was calculating comparing to any other construct in the model. Therefore, the two criteria of discriminant validity were encountered. The resulting implications in all reflective constructs in the measurement model produce different values from each other. For the cross-loading matrix, it explained that all items loaded higher on the construct they were calculating, than on any other constructs in the model. Thus, the two criteria of discriminant validity were met. The implication was that all the reflective constructs in the measurement model were different from each other.

Table 1. Measurement Model

\begin{tabular}{ccccc}
\hline Construct & Item & Loading & AVE & Internal Consistency \\
\hline Attitude & $\mathrm{A} 1$ & 0.796 & 0.613 & 0.887 \\
\hline & $\mathrm{A} 2$ & 0.750 & & \\
\hline $\mathrm{A} 4$ & 0.726 & \\
\hline $\mathrm{A} 5$ & 0.816 & \\
\hline
\end{tabular}




\begin{tabular}{|c|c|c|c|c|}
\hline \multirow[t]{7}{*}{ Barriers } & B1 & 0.768 & 0.657 & 0.930 \\
\hline & B2 & 0.840 & & \\
\hline & B3 & 0.824 & & \\
\hline & B4 & 0.812 & & \\
\hline & B5 & 0.706 & & \\
\hline & B6 & 0.858 & & \\
\hline & B7 & 0.853 & & \\
\hline \multirow[t]{3}{*}{ Interruptions } & 11 & 0.879 & 0.704 & 0.877 \\
\hline & 12 & 0.806 & & \\
\hline & 13 & 0.831 & & \\
\hline \multirow[t]{5}{*}{ Personal Skills } & P1 & 0.895 & 0.740 & 0.934 \\
\hline & $\mathrm{P} 2$ & 0.867 & & \\
\hline & P3 & 0.854 & & \\
\hline & P4 & 0.918 & & \\
\hline & P5 & 0.757 & & \\
\hline \multirow[t]{5}{*}{ Technology Skills } & T1 & 0.816 & 0.663 & 0.908 \\
\hline & $\mathrm{T} 2$ & 0.801 & & \\
\hline & T3 & 0.812 & & \\
\hline & T4 & 0.805 & & \\
\hline & T5 & 0.838 & & \\
\hline
\end{tabular}

Table 2. Discriminant Validity

\begin{tabular}{|c|c|c|c|c|c|}
\hline Construct & A & B & I & $\mathbf{P}$ & $T$ \\
\hline Attitude (A) & 0.783 & & & & \\
\hline Barriers (B) & 0.629 & 0.81 & & & \\
\hline Interruptions (I) & -0.184 & -0.085 & 0.839 & & \\
\hline Personal Skills (P) & -0.231 & -0.127 & 0.531 & 0.86 & \\
\hline Technology Skills (T) & 0.564 & 0.479 & -0.084 & -0.252 & 0.814 \\
\hline
\end{tabular}

\section{Result of Hypothesis Testing}

Table 3. Hypothesis Testing

\begin{tabular}{cccccc}
\hline Hypothesis & Relationship & $\begin{array}{c}\text { Standard Path } \\
\text { Coefficient }\end{array}$ & t-value & P Values & Results \\
\hline H1 & Attitude -> Barriers & 0.534 & $\mathbf{1 1 . 0 2 4}$ & $\mathbf{0 . 0 0 0}$ & Supported \\
\hline H2 & Interruptions -> Barriers & 0.008 & 0.142 & 0.887 & Not Supported \\
\hline H3 & Personal Skills -> Barriers & 0.039 & 0.7433 & 0.458 & Not Supported \\
\hline H4 & Technology Skills $>$ B Barriers & 0.188 & $\mathbf{3 . 5 7 8}$ & $\mathbf{0 . 0 0 0}$ & Supported \\
\hline
\end{tabular}

Note: ${ }^{*} p<0.05$ or ${ }^{* *} p<0.01$

Table 3 shows the summarized hypothesis testing for all variables (attitudes, interruptions, personal skills, and technological skills). The standardized path coefficient indicated whether the relationship's course was positive or negative, and t-value was used to evaluate whether the relationship was significant or not. $\mathrm{H} 1, \mathrm{H} 2, \mathrm{H} 3$ and $\mathrm{H} 4$ explored the effects, respectively, of attitudes, interruptions, personal skills, and technological skills on the barriers to online learning. According to the results, all four variables for standard path coefficients were positive. For $\mathrm{H} 1$, the standardized path coefficient was 0.534 (t-value 0.142 ). The result was acknowledged at $\mathrm{t}<1.96$. Next, $\mathrm{H} 3$ highlighted the standard path coefficient of 0.039 (t-value 0.7433 ). The outcome was accepted at $\mathrm{t}<1.96$. Lastly, for $\mathrm{H} 4$, the result of the standard path coefficient was 0.88 (t-value 3.578 ). In conclusion, only two variables $(\mathrm{H} 1$ and $\mathrm{H} 4)$ from the hypotheses were statistically significant.

\subsection{Discussion}

The results showed the attitude and technology skills has a significant contributor to effective online learning. Attitude is a crucial predictor to measure the students' behavior either they like or dislikes using online learning (Sum, Hericko, Pusnik, \& Polancic, 2011). According to Fauziah (2014), to ensure the successfulness of online learning, technology skills is essential. The interruption and personal skills show insignificant impact towards effective online learning. The findings will be a guideline for higher learning institutions to enhance the online platform and preparing more strategies to ensure the effectiveness of this platform. Furthermore, this research also supported the hypothesis by presenting an empirical evidence relationship between attitude, interruption, personal skills and technology skills. 
Theoretically, this research is pertinent as it contributes to higher learning institutions' improvements in their online methods in both teaching and learning.

\subsection{Conclusion and Recommendations}

This study tested the relationship between attitude, interruption, personal skills, and technology skills towards the barriers to an effective online learning among undergraduates in UiTM Johor. The study's findings showed that attitudes and technology skills have a positive relationship with the barriers to effective online learning. The two other variables namely interruption and personal skills were not significant to explain the barriers. Attitude turned out to be a major barrier as most of the students had negative attitudes towards online learning. This is proven since some students found it difficult to save time, and they experienced uncertainty and anxiety for not having any guidance, especially when the study session involved complex calculations or equations.

Occasionally, online learning can be very intense and uninteresting for students because of its sole focus on learning. This is very different with a classroom's face to face method, where the lecturers sometimes change the lessons with ideas, group activities, and discussions to create interactive and interesting sessions. Furthermore, online learning method also encourages students to learn independently. It certainly creates difficulties especially to students who are weak and lacking extensive knowledge to handling them. The lack of social interaction also contributes to problems that ultimately cause the students to lose focus in their online learning sessions. Technological skills are also very important because they help the students to understand online learning sessions better. Devoid of a good technological skill leads to difficulties for the students when software and advanced technological platforms are used.

Further research is required to test other factors which may assist the exploration of barriers contributing to an effective online learning. The generality of the findings may be limited and only discussed on certain variables, confined to undergraduates of UiTM Johor alone. Thus, other factors like knowledge and facilities can be taken into consideration by future studies. In addition, the study can also be expanded by testing the respondents from students in other higher learning institutions because nowadays, all universities have implemented online learning sessions. To discover the factors contributing to the barriers of online learning implementation, the sample can be represented by several other universities. A varied sample will generate a more effective result for this kind of study.

As a conclusion, this study hopes to contribute to the relevant parties, especially to higher learning institutions in improving the quality of online teaching. The transition to online learning methods is becoming more widespread and practiced by all higher learning institutions in Malaysia. To ensure the effectiveness of online teaching platforms, the parties involved should provide the greatest efforts in making online learning sessions more beneficial for the students. Thus, to ensure a proper transfer of knowledge, the lecturers need to be aware of the factors that can improve the effectiveness of their teaching.

\section{Paper Contribution to Related Field of Study}

This research contributes to fill the gap in the existing literature related to study in factors contributing to an effective online learning among undergraduates' students.

\section{Acknowledgments}

We would like to thank the survey respondents for taking their time to answer the questionnaire and the reviewers of this paper for their valuable comments.

\section{References}

Abdul, H. N., Yusserrie, Z., \& Ramayah, T. (2014). Modelling of Halal Warehouse Adoption Using Partial Least Squares. International Journal of Contemporary Business Management, 1(1), 71-86. https://doi.org/10.13140/RG.2.2.36373.52962

Abramenka, V. (2015). Students' Motivations and Barriers to Online Education.

Allen, I. E., \& Seaman, J. (2013). Changing Course: Ten Years of Tracking Online Education in the United States.

Aziz, N. A. A., Musa, M. H., Ghul, Z. H., Aziz, N. N. A., \& Khalid, R. M. (2018). D eterminants of UITM Johor students' behavioral intention to use e-learning system. International Journal of Engineering \& Technology, 7, 196-199.

Barclay, D., Christopher Higgins, \& Thompsom, R. (1995). The Partial Least Squares (PLS) approach to causal modelling: Personal computer adoption and uses as an illustration. Technology Studies, 2(2), 285-309.

Brandt, D.S. (1996, February). Teaching the net: Innovative techniques in internet training. Paper presented at the 11th Annual Computers in Business Conference Washington, DC.

Chin, W. W., Marcolin, B. L., \& Newsted, P. R. (2003). A Partial Least Squares Latent Variable Modeling Approach for Measuring Interaction Effects: Results from a Monte Carlo Simulation Study and an Electronic-Mail Emotion/Adoption Study. Information System Research.

Conlon, T. (1997). The internet is not a panacea. Scottish Educational Review, 29(1), 30-38. 
Donoghue, J. O., \& Worton, H. (2002). A Study Into The Effects Of eLearning On Higher Education Gurmak Singh. Learning, 133(3), 547-553. https://doi.org/10.1136/icp.2003.013581

Fauziah Sulaiman. (2014). Online Learning in Higher Education in Malaysia: A Case Study of Students' Future Expectations. International Journal of Humanities and Social Science, 4(8), 124-128.

Fornell, C., \& Larcker, D. F. (1981). Evaluating Structural Equation Models with Unobservable Variables and Measurement Error. Journal of Marketing Research, 18(1), 3950.

Harasim,L., Hiltz. S.R., Teles, S. \& Turoff, M. (1997). Learning networks: A field guide to tecahing and learning online. Cambridge, Massachusetts: MIT Press

Holley, D. (2002). " Which room is the virtual seminar in please?". 112-121. https://doi.org/10.1108/00400910210424283

LeBlanc, J. M., Pruchnicki, M. C., Rohdieck, S. V., Khurma, A., \& Dasta, J. F. (2007). An instructional seminar for online case-based discussions. American Journal of Pharmaceutical Education, 71(3). https://doi.org/10.5688/aj710342

Lee, D., Cho, K., lannaccone, G., Moon, S.: Has internet delay gotten better or worse? In: Proceedings of 5 th International Conference on Future Internet Technologies, pp 51-54. ACM (2010)

Lloyd, S. a, Byrne, M. M., \& Mccoy, T. S. (2012). Faculty-Perceived Barriers of Online Education. Journal of Online Learning and Teaching, 8(1), 1-12.

Muilenburg, L. Y., \& Berge, Z. L. (2005). Student Barriers to Online Learning : A factor analytic study. 26(1), 29-48. https://doi.org/10.1080/01587910500081269

O'Hearn, J. (2000). Challenges for service leaders: setting the agenda for the virtual learning organization. International Journal of Contemporary Hospitality Management, 12(2), $97-106$.

Oliver, R. (2001). Assuring the quality of online learning in Australian higher education. Proceedings of Moving Online II Conference, (2001), $222-231$.

Oliver, R. (2001). Exploring the development of critical thinking skills through a Web-supported problem-based learning environment. In J. Stephenson (Ed.), Teaching and Learning Online: Pedagogies for New Technologies (pp. 98-111). London: Kogan Page.

Oliver, R., \& Towers, S. (2000). Up time: Information Communication Technology: Literacy and Access for Tertiary Students in Australia. Canberra: Department of Education, Training and Youth Affairs.

Peytcheva-Forsyth, R., Yovkova, B., \& Aleksieva, L. (2018). Factors affecting students' attitudes towards online learning - The case of Sofia University Factors Af fecting Students' Attitudes Towa rds Online Learning - The Case of Sofia University. AIP Conference Proceedings 2048, 020025 (2018); 020025(December), 1-18.

Pirani, J. A. (2004). Supporting E-learning in Higher Education. October, (July).

Sum, B., Hericko, M., Pusnik, M., \& Polancic, G. (2011). Factors Affecting Acceptance and Use of Moodle: An Empirical Study Based on TAM. 35, 91-100.

Volery, T. (2000). Critical success factors in online education. The International. The International Journal of Educational Management, 14(5), 216-233.

Wilson, J. (2001). Lessons of a Virtual Timetable: Education. The Economist, (17 February), p. 1 (CDROM). 